\title{
Consequences and economics of metritis in Iranian Holstein dairy farms
}

\author{
A. Mahnani, ${ }^{*}$ A. Sadeghi-Sefidmazgi, ${ }^{*}$ and V. E. Cabrera ${ }^{1}$ \\ *Department of Animal Science, College of Agriculture, Isfahan University of Technology, PO Box 84156, Isfahan, Iran \\ †Department of Dairy Science, University of Wisconsin, Madison 53706
}

\begin{abstract}
The objectives of this study were (1) to describe the risk factors, incidence, and productive and reproductive consequences of metritis in dairy cows, and (2) to estimate the financial losses associated with metritis using data gathered from 4 Holstein dairy farms in Isfahan, Iran. Calving records from March 2008 to December 2013, comprising 43,488 calvings, were included in the data set. The effects of metritis on productive and reproductive performance were analyzed using a mixed linear model for primiparous and multiparous cows separately and in an overall data set (all cows combined), whereas risk factors on metritis incidence were examined using a multivariable logistical regression model for the overall data set. The incidence of metritis per cow per year was $13.2 \%$ on average and ranged from 9.0 to $15.8 \%$. Results of logistic regression analysis demonstrated that calving year, parity number, calving season, twinning, dystocia, and retained placenta were significantly associated with the occurrence of metritis, whereas previous metritis incidence did not show an association. Greatest odds of metritis occurred in first-parity cows that calved in winter and had retained placenta, twinning, and dystocia in recent years. A case of metritis significantly reduced the 305-d milk yield in primiparous and multiparous cows and overall, but had no significant effects on 305-d fat and protein percentages in either primiparous or multiparous cows. Overall, a case of metritis reduced 305-d milk yield by 129.8 $\pm 41.5 \mathrm{~kg} /$ cow per lactation. The negative reproductive effects due to metritis were smaller and nonsignificant for primiparous cows compared with multiparous cows. Overall, a case of metritis increased days open and number of insemination per conception by $16.4 \pm 1.2$ and $0.1 \pm 0.0$ per cow per lactation, respectively. Among the individual farms, metritis costs ranged from $\$ 146.4$ to $\$ 175.7$ with a mean of $\$ 162.3 /$ case. The model to calculate metritis costs proposed here could be used to estimate economic losses for metritis in other devel-
\end{abstract}

Received September 16, 2014.

Accepted May 11, 2015.

${ }^{1}$ Corresponding author: vcabrera@wisc.edu oping countries, where farm productive and economic data are generally scarce.

Key words: risk factors, health cost assessment, reproduction disease, milking cow

\section{INTRODUCTION}

Metritis is one of the most common reproductive diseases occurring within $21 \mathrm{~d}$ after calving and it is often characterized by fetid, red-brown, watery uterine discharge (Sheldon et al., 2006). Metritis is known to reduce milk yield (Rajala and Gröhn, 1998) and reproductive performance (Opsomer et al., 2000; Melendez et al., 2004) and to negatively affect the productive life of a dairy cow through increased culling rates (Gröhn et al., 2003).

There is a wide range for reported lactational incidence rates of metritis for dairy cows in the literature, varying from very low rates $(0.2 \%)$ in Finland (Roine and Saloniemi, 1978) to extremely high levels $(69 \%)$ in Canadian herds (Urton et al., 2005). This is partially due to poor diagnostic criteria used to classify uterine infections among studies as well as inconsistencies in disease definition and different levels of detection intensity. Practical methods for improved health monitoring, therefore, would be useful (Huzzey et al., 2007).

Risk factors associated with metritis include (1) diseases such as dystocia, retained placenta, abortion, displaced abomasum, ketosis, and milk fever (Gröhn et al., 1990; Kaneene and Miller, 1995); and (2) nondisease factors such as herd management (herd size and housing), age, parity, and calving season (Kaneene and Miller, 1995; Bruun et al., 2002). However, there is some controversy among investigators about risk factors and consequences of metritis (Kaneene and Miller, 1995; Rajala and Gröhn, 1998; Bruun et al., 2002; Goshen and Shpigel, 2006; Wittrock et al., 2011) because research goals, study methodology, and quantification criteria differ greatly from study to study. These need to be considered in the estimation of economic losses associated with metritis.

In addition to the cost of medicines and veterinary services, metritis decreases milk yield, decreases reproductive efficiency, increases early culling, and increases 
Table 1. Characteristics of the data for the 4 investigated herds in the Isfahan province of Iran

\begin{tabular}{lcrrrr}
\hline & \multicolumn{4}{c}{ Farm } & \\
\cline { 2 - 5 } Variable & \multicolumn{1}{c}{1} & \multicolumn{1}{c}{3} & \multicolumn{1}{c}{ Mean } \\
\hline Average calving events per herd per yr (no.) & 3,223 & 1,199 & 1,037 & 1,988 & 1,862 \\
Number of metritis cases per herd per yr (no.) & 483 & 189 & 137 & 179 & 247 \\
Average incidence of metritis (\%) & 15.0 & 15.8 & 13.2 & 9.0 & 13.3 \\
305-d milk yield (kg) & 11,733 & 12,148 & 11,610 & 10,900 & 11,598 \\
Age at first calving (d) & 746 & 743 & 756 & 777 & 756 \\
Dry days (d) & 59.4 & 58.4 & 59.9 & 60.7 & 59.6 \\
Average parity per cow per herd & 2.7 & 2.6 & 2.8 & 2.3 & 2.6 \\
Open days (d) & 142.4 & 139.4 & 148.3 & 131.2 & 140.4 \\
Average incidence of twinning (\%) & 2.4 & 5.0 & 3.4 & 3.0 & 3.4 \\
Average incidence of retained placenta (\%) & 10.2 & 11.2 & 12.6 & 9.0 & 10.8 \\
Average incidence of dystocia (\%) & 21.5 & 21.4 & 18.4 & 27.9 & 22.3 \\
\hline
\end{tabular}

labor and replacement costs (Dubuc et al., 2011; Wittrock et al., 2011; Giuliodori et al., 2013).

Recording production data for individual cows in Iran goes back to the early 1980s. However, no data for metritis have been yet documented in the central milkrecording database and no detailed evaluation of costs associated with metritis has been conducted. Although farmers consider metritis as one of the most important problems in their production system (e.g., Kaneene and Miller, 1995 in the United States; Bruun et al., 2002 in Denmark; Giuliodori et al., 2013 in Argentina), the economic importance of metritis has received only limited attention (Bartlett et al., 1986; Drillich et al., 2001; Overton and Fetrow, 2008).

Therefore, the objectives of this study were 2-fold: (1) describe the risk factors, incidence, and productive and reproductive consequences of metritis in dairy cows; and (2) estimate the financial losses associated with metritis using data gathered from 4 Holstein dairy farms in Isfahan, Iran.

\section{MATERIALS AND METHODS}

\section{Description of Farms and Data}

This study was conducted with data from a sample of 4 large Holstein dairy farms distributed in Isfahan province of Iran, where most of the cow husbandries are located. All of the participating farms were under official performance and pedigree recording. Farms were of different sizes, animals were housed differently across the farms, and each had their own specific feeding and management policies. All cows were raised in intensive production systems with freestall barns. On all farms, cows were fed, 3 times per day, a balanced TMR that consisted of corn silage, alfalfa, dehydrated beet pulp, barley and corn grain ground, soybean meal, canola meal, cotton seed, cotton seed meal, corn gluten meal, extruded soybean, fish meal, protected fat powder, sodium bicarbonate, salt, macro- and micro-minerals, vitamin supplement, and feed additives. Lactating cows were milked 3 times per day.

Calving records from March 2008 to December 2013, comprising 43,488 calvings, were included in the data set. Information for individual calving events, including herd identification, sire and cow identification, successful insemination date, calving date, age at first calving, parity, 305-d milk, fat, and protein percentages, as well as occurrence of metritis, twinning, dystocia, and retained placenta were included in the data set. A summary of the data is given in Table 1 .

Isfahan province is located in an arid climate with 4 distinct seasons. Months of birth were grouped into 4 seasons: January through March (winter), April through June (spring), July through September (summer), and October through December (fall). The annual mean precipitation is about $120 \mathrm{~mm}$ and there is usually no rainfall during summer. The average annual temperature is $16^{\circ} \mathrm{C}$ and ranges from $-10^{\circ} \mathrm{C}$ (in January) to $45^{\circ} \mathrm{C}$ (in July). Relative humidity typically ranges from 10 to $88 \%$, with an average of $30 \%$ (Iran Meteorological Organization, 2014).

Recognized dystocia scores were $1=$ no assistance, $2=$ slight assistance, $3=$ difficult calving (mechanical assistance), $4=$ difficult calving (veterinary assistance), $5=$ calving requiring caesarean. In the present study, dystocia scores of 1 or 2 were coded as easy calving, and scores of $\geq 3$ were coded as difficult calvings. Stillbirth was defined as dead at birth or within $48 \mathrm{~h}$ after birth. The number of calves born per calving event was coded as a dichotomous variable $(0=$ singleton; $1=$ twin $)$.

Metritis in this study refers to cows having an abnormally enlarged uterus, abnormal watery fetid discharge, and sometimes showing signs of systemic illness (especially fever and low appetite) until $21 \mathrm{~d}$ after calving. Within each parity, absence or presence of metritis was scored as 0 or 1 , respectively, based on whether or not the cow had at least one veterinary treatment recorded. 


\section{Statistical Analyses}

Statistical procedures were conducted using SAS/ STAT 9.1 (SAS Institute Inc., Cary, NC). The potential effects of metritis on lactation milk production traits and reproductive performance were analyzed using a mixed linear model (PROC MIXED) with class statements for herd, calving year and season, parity, and occurrences of metritis, twinning, dystocia, and retained placenta. The population data were analyzed based on primiparous cows, multiparous cows, and all cows. The statistical model used for analyses was:

$$
\begin{aligned}
y_{i j k l m n o p q r s t u} & =\mu+\text { Herd }_{i}+\text { Parity }_{j}+\text { Cyear }_{k}+\text { Season }_{l}+\beta_{1 m} \\
& \times\left(D I M_{i j m}-\overline{D I M}\right)+\beta_{2 n}\left(D D_{i j n}-\overline{D D}\right) \beta_{3 o} \\
& \times\left(A F C_{i j o}-\overline{A F C}\right)+M E T_{p}+T W N_{q}+D Y S_{r} \\
& +R P_{s}+\text { Anim }_{t}+\text { Sire }_{u}+e_{i j k l m n o p q r s t u}
\end{aligned}
$$

where $y_{i j k l m n o p s r s t u}=$ dependent variable (milk production traits or reproductive performance); $\mu=$ the overall mean; Herd $_{i}=$ the fixed effect of herd $i$; Parity $y_{j}=$ the fixed effect of parity $j ; C_{y e a r}=$ the fixed effect of $k$ th year of calving; Season ${ }_{l}=$ the fixed effect of $l$ th season of calving; $\beta_{1 m}=$ regression coefficient of observations on DIM as a covariate, only for milk yield traits and $\overline{D I M}$ is the DIM mean; $\beta_{2 n}=$ regression coefficient of observations on previous days dry (DD) as a covariate, for all investigated traits on multiparous cows and $\overline{D D}$ is the DD mean; $\beta_{30}=$ regression coefficient of observations on age at first calving (AFC) as a covariate, for all investigated traits and $\overline{A F C}$ is the AFC mean; $M E T_{p}=$ the fixed effect of cow's metritis status $(2$ categories; normal or affected); $T W N_{q}=$ the fixed effect of number of calves at birth $(1=$ singleton and $2=$ twin); $D Y S_{r}=$ the fixed effect of dystocia at calving (2 categories; normal calving $=0$ and difficult calving $=$ $1) ; R P_{s}=$ the fixed effect of cow's retained placenta status (2 categories; normal or affected); Anim $_{t}=$ the random effect of animal $t$ (primiparous or multiparous cow); Sire $_{u}=$ the random effect of sire $u ; \mathrm{e}_{i j k l m n o p s r s t u}=$ random residual effect with mean 0 and homogeneous variance $\sigma^{2}$. For all statistical analyses, significance was declared at $P<0.05$ and trends at $P \leq 0.10$. Residual diagnostics did not indicate any concern for departure from the statistical assumption of normality.

Using a multivariable logistical regression procedure (PROC LOGISTIC), the potential effects of environmental risk factors on metritis incidence rate were examined simultaneously. The regression model was formulated as follows:

$$
\operatorname{Logit}(\pi)=\alpha+\beta_{1} X_{1}+\beta_{2} X_{2}+\ldots+\beta_{n} X_{n},
$$

where $\pi=$ the odds of metritis; $\alpha=$ the intercept parameter; $\beta_{1}$ to $\beta_{n}=$ the logistic regression coefficients (parameter estimates) for the explanatory effects $\left(X_{1}\right.$ to $\left.X_{n}\right)$ included in the statistical model. The model used to analyze metritis incidence included the fixed class effects of herd, calving year, calving season, parity, twinning, and incidence of dystocia, retained placenta, and previous metritis. Model specification was based on the backward elimination method, and the fit of statistical model was evaluated by using goodness-of-fit test by including the lackfit option in the model statement.

\section{Economic Calculations}

Economic data were provided by farmers via a questionnaire or estimated by cost and revenue modeling. Data sources used for deriving economic input parameters were based on the marketing circumstances of Iran in 2012. The currency used in Iran is the rial; however, costs and prices were converted and expressed in US dollars, assuming an exchange rate of US $\$ 1=$ 30,000 rials. Input parameters used for the calculation of financial losses caused by metritis for the 4 investigated farms of the Isfahan province of Iran are listed in Tables 2, 3, and 6 .

We developed a model to calculate costs due to metritis, as follows:

Metritis cost $(\$ /$ case per lactation $)=$ reduction

in milk production costs + loss of revenues for discarded milk during illness + reduction in fertility costs + replacement costs due to metritis occurrence

$$
\begin{aligned}
& + \text { cost for drugs and veterinary service } \\
& + \text { cost of labor. }
\end{aligned}
$$

The reduction in milk production costs $(\$ /$ case) was calculated as the reduced amount of milk $(\mathrm{kg})$ multiplied by milk profit $(\$ / \mathrm{kg})$. The loss of revenue for discarded milk during illness of cows (\$/case) was calculated as amount of discarded milk ( Disc $_{\text {milk }}$ ) multiplied by the milk price $(\$ / \mathrm{kg})$; Disc milk $(\mathrm{kg} /$ case $)$ was estimated as follows: average daily milk yield (ADMY, $\mathrm{kg} / \mathrm{cow}) \times$ duration of therapy during which milk is discarded (DT, d).

The reduction in fertility costs $(\$ /$ case) was calculated as the longer open days (d/case) multiplied by cost of an extra open day $(\$ / d)$. The methodology presented by Cabrera (2012) for the economic value of a cow was used to calculate cost of an extra day open under different production circumstances of the 4 investigated farms on the Isfahan province of Iran. The cost of a day 
Table 2. Biological, management, and economic input parameters used in Cabrera (2012; http://dairymgt. info/ $\rightarrow$ Tools $\rightarrow$ The Economic Value of a Dairy Cow) model to calculate the cost of an extra day open for an average cow for the 4 investigated dairy farms of the Isfahan province of Iran

\begin{tabular}{|c|c|c|c|}
\hline Variable & Mean \pm SD & Minimum & Maximum \\
\hline \multicolumn{4}{|l|}{ Cow variable evaluated } \\
\hline Current lactation & $2 \pm 0.8$ & 1 & 3 \\
\hline Current month after calving or month in milk (MIM) & $6 \pm 2.7$ & 2 & 10 \\
\hline Current month in pregnancy & & 0 & 0 \\
\hline \multicolumn{4}{|l|}{ Herd variables } \\
\hline Herd turnover ratio $(\% / y r)$ & $37.8 \pm 3.2$ & 35 & 43 \\
\hline Rolling herd average (kg/cow per year) & $10583 \pm 928$ & 9,530 & 11,790 \\
\hline $21-\mathrm{d}$ pregnancy rate $(\%)$ & $20.7 \pm 2.5$ & 18 & 24 \\
\hline Reproduction cost (\$/cow per month) & $12.3 \pm 2.0$ & 10 & 15 \\
\hline Last MIM to breed a cow & $8.3 \pm 1.2$ & 7 & 10 \\
\hline Milk threshold ( $\mathrm{kg} /$ cow per day) & & 22.7 & \\
\hline Pregnancy loss after $35 \mathrm{~d}$ pregnant $(\%)$ & & 22.6 & \\
\hline Average cow BW (kg) & $616.7 \pm 28.7$ & 580 & 650 \\
\hline \multicolumn{4}{|l|}{ Economic variables } \\
\hline Replacement cost $(\$ /$ cow $)$ & $2,692.3 \pm 101.7$ & 2,545 & 2,756 \\
\hline Salvage value ( $\$ / \mathrm{kg}$ of live weight) & $1.8 \pm 0.04$ & 1.7 & 1.8 \\
\hline Calf value $(\$ /$ calf $)$ & $670 \pm 21.2$ & 650 & 700 \\
\hline Milk price $(\$ / \mathrm{kg})$ & $0.32 \pm 0.005$ & 0.31 & 0.32 \\
\hline Milk butterfat (\%) & & 3.2 & \\
\hline Feed cost for lactating cows ( $\$ / \mathrm{kg}$ of $\mathrm{DM}$ of diet) & & 0.45 & \\
\hline Feed cost for dry cows $(\$ / \mathrm{kg}$ of $\mathrm{DM}$ of diet) & & 0.3 & \\
\hline Interest rate $(\% / y r)$ & & 22 & \\
\hline Calculated cost of an extra day open $(\$ / d)$ & $4.0 \pm 0.3$ & 3.6 & 4.1 \\
\hline
\end{tabular}

open was defined as the decreased cow value between 2 successive days when a cow does not become pregnant (Shahinfar et al., 2014a,b). Assumptions about the biological, management, and economic parameters used in the Cabrera (2012) model are listed in Table 2.

The replacement costs due to metritis occurrence (premature culling; \$/case) was calculated as proportion of cow culled because of metritis $\times$ cost of culling. The value of culling was estimated according to the methodology proposed by Dorshorst et al. (2006). We assumed that the culled animal was immediately replaced by a pregnant heifer with the same production level as the culled animal. The biological and economic input parameters used to calculate the valuation of culling for the 4 farms and the mean values across the 4 farms are summarized in Table 3 . The value of male and female calves varied across investigated farms. A weighted average value of a calf was calculated, assuming the probability that the replacement heifer delivered a female calf was $48 \%$ in all farms. The total cost of culling (TCC) was calculated by subtracting the culled cow price (i.e., salvage value) and the value of the calf from the value of the replacement heifer price. Discounting was used to calculate the cost of culling relative to the expected productive life of a cow. The expected number of months (ELM) for a cow in each farm was calculated as 1 divided by cull rate, and multiplied by 12 . According to the Central Bank of Iran, a very high annual discount rate of $22 \%$, which represents the true interest cost in Iran, was used in the calculations (CBI, 2014). Therefore, the monthly interest rate (IR) was $1.81 \%$ and the monthly cost of culling (MCC) was estimated using the following equation:

$$
M C C=\frac{T C C \times I R}{1-(1+I R)^{-E L M}} .
$$

Among individual farms, the monthly cost of culling ranged from $\$ 29.3$ to $\$ 40.2$ with a mean of $\$ 36.0$. The MCC value was then used to calculate the valuation of culling in terms of the month in milk (MIM) when the culling occurred for primiparous and multiparous cows. For example, if a primiparous cow was culled at 2 MIM, 30 mo $(32-2)$ would be considered lost, resulting in culling cost of $\$ 1,080(30 \times \$ 36.0)$. The cost of culling for a multiparous cow was assumed for a second-parity cow. The average calving interval was estimated to be 14 mo among investigated farms. For example, if a multiparous cow was culled at 3 MIM, 15 mo would be considered lost (i.e., $32-14-3=15$ ), resulting in cost of culling of $\$ 540$. The cost of culling was calculated according to the assumed MIM when the culling occurred, which ranged from 1 to 10. The valuation of culling was finally considered as an average culling cost estimated for primiparous and multiparous cows across MIM for each farm separately.

The cost for drugs and veterinary service was calculated as drug costs (\$/case) + time of veterinary service (hours per clinical metritis case) $\times$ cost of veterinary 
Table 3. Biological and economic input parameters used to calculate the valuation of culling for the 4 investigated dairy farms of the Isfahan province of Iran

\begin{tabular}{lrrrrr}
\hline & \multicolumn{4}{c}{ Farm } & \\
\cline { 2 - 5 } Variable & 1 & 2 & 3 & 4 & Mean \\
\hline Replacement heifer price (\$) & 2,756 & 2,812 & 2,545 & 2,656 & 2,692 \\
Average value of calf (\$) & 650 & 680 & 700 & 650 & 670 \\
Culled cow price (\$) & 1,178 & 1,162 & 1,145 & 1,131 & 1,154 \\
Total cost of culling (\$) & 928 & 970 & 700 & 875 & 868 \\
Calving interval (mo) & 14.0 & 13.9 & 14.2 & 13.6 & 13.9 \\
Culling rate (\%) & 35.0 & 35.0 & 38.0 & 43.0 & 37.8 \\
Expected productive life (mo) & 34.3 & 34.3 & 31.6 & 27.9 & 32.0 \\
Monthly interest rate (\%) & 1.8 & 1.8 & 1.8 & 1.8 & 1.8 \\
Monthly cost of culling (\$) & 36.5 & 38.2 & 29.3 & 40.2 & 36.0 \\
Average value of culling (\$/head) & & & & & \\
Primiparous cows (no.) & 1,051 & 1,099 & 763 & 900 & 953 \\
Multiparous cows (no.) & 539 & 568 & 347 & 352 & 452 \\
Overall (no.) & 795 & 833 & 555 & 626 & 702 \\
\hline
\end{tabular}

service $(\$ / \mathrm{h})$. The cost of labor $(\$ /$ case $)$ was calculated as the herdsman's time for dealing with clinical metritis $\times$ price of herdsman's time $(\$ / h)$.

Because all cows with metritis were treated with antibiotics, milk obtained during the illness period (duration therapy) was assumed discarded and not fed to calves because of risk of antibiotic residuals and pathogen contamination. The costs for drugs were calculated for each farm based on the type and number of medications per case of metritis. Price and time of veterinary service, herdsman's time, and price of herdsman's time were also calculated on the basis of individual contracts between the farms, veterinarians, and herdsman. The price per dose of all drugs corresponded approximately to the prices of veterinary drugs in Iran in 2012.

\section{RESULTS AND DISCUSSION}

\section{Productive and Reproductive Consequences}

Estimated least squares means for the effects of metritis on production and reproduction performance of the 4 investigated farms of the Isfahan province of Iran are shown in Table 4. The effects are shown for primiparous and multiparous cows separately and for all cows (overall). The least squares means results showed that a case of metritis significantly $(P<0.05)$ reduced 305 -d milk yield in multiparous cows and in all cows but had no significant effects $(P \geq 0.05)$ on 305-d fat and protein percentages in either primiparous or multiparous cows (Table 4). Overall, 305-d milk production for affected cows was $11,947 \pm 61.1 \mathrm{~kg}$ compared with $12,077 \pm 58.9 \mathrm{~kg}$ for healthy cows. Therefore, a case of metritis reduced $305-\mathrm{d}$ milk yield by $129.8 \pm 41.5 \mathrm{~kg} /$ cow per lactation (Table 4).

Previously, production losses from metritis were measured on a short-term basis from calving until a certain stage of lactation (e.g., Østergaard and Gröhn, 1999) or evaluated by a summary measure such as 305-d milk yield (e.g., Rajala and Gröhn, 1998). The results from our overall data set analyses are in general agreement with previous reports that found lower milk production in cows with metritis (Rajala and Gröhn, 1998; Dubuc et al., 2011; Wittrock et al., 2011). Some other studies have reported no or equivocal effects of the disease on yield (e.g., Goshen and Shpigel, 2006). This discrepancy may be partly explained by differences in case definition, detection intensity, recording approach, statistical methods, and parity. Østergaard and Gröhn (1999) found that multiparous cows, but not primiparous cows, with metritis produced less milk than healthy cows up to 6 wk after diagnosis. We found no losses in milk production traits for primiparous cows. This could be partially ascribed to the statistical approach used in the study to evaluate production losses from the disease. Metritis may have a short-term effect on milk production traits that may not be detected by a summary criterion (lactational performance), as discussed by Østergaard and Gröhn (1999). A short-term effect might be compensated for by later performance. Furthermore, culling associated with metritis may lead to an underestimation of the effect of disease (Østergaard and Gröhn, 1999). However, the latter issue may be negligible if the culling rate due to metritis is very low, as shown in the current study $(<1 \%)$. It should also be noted that the approach of using lactational (305 d) performance might not be sensitive or accurate enough to account for the production consequences of metritis, as discussed by Wittrock et al. (2011) and Giuliodori et al. (2013). Consequently, our results might underestimate the effect of metritis on milk production.

Metritis incidence was shown to have a negative effect $(P<0.05)$ on reproduction efficiency. Table 4 highlights the differences in open days as well as num- 
Table 4. Estimated least squares means $( \pm \mathrm{SE})$ for the effects of metritis on production and reproduction performance of 4 investigated farms on the Isfahan province of Iran $(\mathrm{n}=43,487)$

\begin{tabular}{|c|c|c|c|}
\hline \multirow[b]{2}{*}{ Variable } & \multicolumn{2}{|c|}{ Cow status for metritis } & \multirow[b]{2}{*}{ Difference $^{1}$} \\
\hline & Normal & Affected & \\
\hline \multicolumn{4}{|c|}{ 305-d milk yield $(\mathrm{kg})$} \\
\hline Primiparous & $11,574.0( \pm 174.6)$ & $11,556.0( \pm 176.2)$ & NS \\
\hline Multiparous & $12,258.0( \pm 68.6)$ & $12,066.0( \pm 71.9)$ & $192.5( \pm 54.0)^{* *}$ \\
\hline Overall & $12,077.0( \pm 58.9)$ & $11,947.0( \pm 61.1)$ & $129.8( \pm 41.5)^{* * *}$ \\
\hline \multicolumn{4}{|c|}{ 305-d fat percentage (\%) } \\
\hline Primiparous & $3.1( \pm 0.1)$ & $3.0( \pm 0.1)$ & NS \\
\hline Multiparous & $3.0( \pm 0.1)$ & $3.0( \pm 0.1)$ & NS \\
\hline Overall & $3.1( \pm 0.1)$ & $3.0( \pm 0.1)$ & NS \\
\hline \multicolumn{4}{|c|}{305 -d protein percentage $(\%)$} \\
\hline Primiparous & $2.9( \pm 0.0)$ & $2.9( \pm 0.0)$ & NS \\
\hline Multiparous & $3.0( \pm 0.1)$ & $3.0( \pm 0.1)$ & NS \\
\hline Overall & $2.9( \pm 0.0)$ & $2.9( \pm 0.0)$ & NS \\
\hline \multicolumn{4}{|l|}{ Days open (d) } \\
\hline Primiparous & $90.2( \pm 12.3)$ & $106.0( \pm 12.3)$ & $15.8( \pm 2.0)^{* * *}$ \\
\hline Multiparous & $123.4( \pm 7.8)$ & $139.7( \pm 7.9)$ & $16.4( \pm 1.5)^{* * *}$ \\
\hline Overall & $120.2( \pm 8.3)$ & $136.6( \pm 8.4)$ & $16.4( \pm 1.2)^{* * *}$ \\
\hline \multicolumn{4}{|c|}{ No. of inseminations per conception } \\
\hline Primiparous & $2.6( \pm 0.1)$ & $2.6( \pm 0.1)$ & NS \\
\hline Multiparous & $2.8( \pm 0.2)$ & $3.0( \pm 0.2)$ & $0.2( \pm 0.0)^{* *}$ \\
\hline Overall & $2.7( \pm 0.2)$ & $2.9( \pm 0.2)$ & $0.1( \pm 0.0)^{* *}$ \\
\hline
\end{tabular}

ber of inseminations per conception of Holstein dairy cows experiencing metritis compared with normal cows. The negative reproductive effects due to metritis were smaller and nonsignificant for primiparous cows compared with multiparous cows. Overall, results showed that a case of metritis increased days open and number of inseminations per conception by $16.4 \pm 1.2$ and 0.1 \pm 0.0 per cow per lactation, respectively (Table 4 ). Although we detected a significant association between studied reproduction criteria and metritis incidence, the results may be influenced in part by the nature of studied traits or herd management: decisions by the herd owner to postpone first inseminations for cows with metritis or cull them will affect days open and number of insemination per conception (Elkjær et al., 2013). In Iran, however, the investigated traits are systematically recorded and are more accurate than other reproduction parameters. To reduce the consequences of these pitfalls in our research, we adjusted for possible effects of differences between herds by introducing a fixed component representing herd. We also adjusted for possible changes in management over time by adding the year and season of calving components to the analyses.

The results obtained in the study were not surprising. The negative effects of metritis on reproduction performance are well established. As reviewed by Fourichon et al. (2000), the negative effects of metritis could affect fertility in 3 main ways: (1) delay the return to cyclicity after parturition, (2) disrupt the uterine environment, or (3) impair embryo development.

In studied farms, all cows with metritis were treated, but despite treatment, productive and reproductive performance were still impaired. Thus, we expect that the negative effect of metritis would be even worse if cows had not been treated.

Metritis may be either puerperal or clinical uterine infections, as defined by Sheldon et al. (2006). Some studies on metritis in dairy cows have used fever as an inclusion criterion (Drillich et al., 2001; Benzaquen et al., 2007; Huzzey et al., 2007), and it seems that metritis with fever (puerperal) has a more pronounced negative effect on productive and reproductive performance than metritis without fever (clinical). In spite of the large data set, our observational study did not use a standardized disease definition and it was not possible to distinguish between puerperal and clinical metritis.

\section{Metritis Frequency and Risk Factors Affecting Metritis}

Estimated odds ratios (OR) for the effects of calving year, parity, calving season, twinning, dystocia, and retained placenta on reported metritis rates of Holstein cows are shown in Table 5 . Results of logistic regression analysis demonstrated that calving year, parity number, calving season, twinning, dystocia, and retained placenta were significantly $(P<0.001)$ associated with 
Table 5. Estimated odds ratios (95\% CI) for the effects of calving year, parity, calving season, twinning, dystocia, retained placenta, and previous metritis incidence on reported metritis incidence rates of Holstein cows $(\mathrm{n}=43,487)$

\begin{tabular}{|c|c|c|c|c|}
\hline Variable & $\begin{array}{l}\text { No. of } \\
\text { calvings }\end{array}$ & $\begin{array}{c}\text { Metritis } \\
\text { incidence (\%) }\end{array}$ & $\begin{array}{l}\text { Odds ratio } \\
(95 \% \mathrm{CI})\end{array}$ & $P$-value \\
\hline Calving year & & & & $<0.0001$ \\
\hline 2008 & 5,898 & 12.1 & Referent & \\
\hline 2009 & 6,970 & 11.6 & $1.0(0.8-1.0)$ & \\
\hline 2010 & 7,667 & 12.6 & $1.2(1.1-1.3)$ & \\
\hline 2011 & 8,312 & 14.9 & $1.5(1.4-1.7)$ & \\
\hline 2012 & 9,084 & 14.4 & $1.4(1.3-1.6)$ & \\
\hline 2013 & 5,556 & 16.3 & $1.6(1.4-1.8)$ & \\
\hline Parity & & & & $<0.0001$ \\
\hline 1 & 13,990 & 16.4 & Referent & \\
\hline 2 & 11,179 & 11.8 & $0.6(0.6-0.7)$ & \\
\hline 3 & 7,764 & 12.0 & $0.6(0.6-0.7)$ & \\
\hline 4 & 4,900 & 12.2 & $0.6(0.6-0.7)$ & \\
\hline 5 & 2,822 & 13.3 & $0.7(0.6-0.8)$ & \\
\hline$\geq 6$ & 2,832 & 15.0 & $0.8(0.7-0.9)$ & \\
\hline Calving season & & & & $<0.0001$ \\
\hline Spring & 9,637 & 14.0 & Referent & \\
\hline Summer & 12,258 & 13.5 & $1.0(0.9-1.0)$ & \\
\hline Autumn & 12,273 & 12.8 & $0.9(0.8-1.0)$ & \\
\hline Winter & 9,319 & 14.8 & $1.3(1.2-1.4)$ & \\
\hline Birth number & & & & $<0.0001$ \\
\hline Singletons & 42,162 & 13.0 & Referent & \\
\hline Twin births & 1,325 & 33.7 & $3.3(2.9-3.7)$ & \\
\hline Calving type & & & & $<0.0001$ \\
\hline Normal & 33,793 & 13.9 & Referent & \\
\hline Dystocia & 9,694 & 19.4 & $1.4(1.3-1.5)$ & \\
\hline Retained placenta & & & & $<0.0001$ \\
\hline Normal & 38,812 & 10.0 & Referent & \\
\hline Abnormal & 4,675 & 53.7 & $15.2(14.0-16.5)$ & \\
\hline Previous metritis incidence & & & & 0.61 \\
\hline No & 4,711 & 81.8 & Referent & \\
\hline Yes & 1,045 & 18.2 & $0.1(0.0-99.0)$ & \\
\hline
\end{tabular}

the occurrence of metritis, whereas previous metritis incidence showed no significant association $(P=0.66$; Table 5).

The incidence of metritis across studied dairy farms ranged from 9.0 to $15.8 \%(P<0.001)$, as shown in Table 1 . The incidence of metritis in the literature ranges from 0.2 to $69 \%$ in dairy farms (Roine and Saloniemi, 1978; Urton et al., 2005). This wide range in incidence can be attributed in part to inconsistency in diagnosis and the lack of a clear definition of the disease in the literature (LeBlanc et al., 2002). However, differences in herd management such as housing type, herd size, veterinary presence, and genetic makeup may allow some control of the incidence of metritis (Kaneene and Miller, 1995).

The percentages of metritis at parity $1,2,3,4,5$ and $\geq 6$ were $16.4,11.8,12.0,12.2,13.3$, and 15.0 , respectively. The odds of metritis decreased from parity 1 to parity $\geq 6(P<0.001$; OR $=0.8$; parity $\geq 6$ vs. parity 1; Table 5). However, the odds increased from parity 4 to parity $5(\mathrm{OR}=1.1$; parity 5 vs. parity 4$)$ and from parity 5 to parity $\geq 6(\mathrm{OR}=1.2$; parity $\geq 6$ vs. parity $5 ; 95 \% \mathrm{CI}=1.0$ to 1.3 ; data not shown). Animal par- ity and its association with metritis are controversial. Some investigators have found no association between metritis and parity (e.g., Gröhn et al., 1990). However, the U-shaped association between parity and metritis has more support in the literature (e.g., Bruun et al., 2002) and can be explained biologically. First-parity cows have greater odds of metritis than second-parity cows because damage to the uterus is more common in younger cows. Also, first-parity cows that are unsuccessful at calving are likely to be culled. Third-parity cows could have higher odds of metritis compared with second-parity cows due to delayed involution of the uterus, with increased risk of infection (Bruun et al., 2002).

Metritis incidence increased over the years from $12.1 \%$ in 2008 to $16.3 \%$ in $2013(\mathrm{OR}=1.6 ; P<0.001$; 2013 vs. 2008; Table 5). This is in agreement with previous reports that found an increasing trend for the odds of metritis in dairy cows during the past decade (Bruun et al., 2002; Urton et al., 2005).

Metritis incidence changed over seasons (Table 5). The greatest odds of metritis was observed in winter $(\mathrm{OR}=1.3 ; P<0.001 ;$ winter vs. spring $)$, and fall 
showed the lowest odds of metritis $(\mathrm{OR}=0.9 ; P<$ 0.001; autumn vs. spring). The greatest incidence of metritis was in winter months compared with other seasons and this is supported in the literature (Gröhn et al., 1990; Bruun et al., 2002). The seasonal variation in reported metritis incidence can be explained by variations in the ambient temperature. The general health of cows is reduced during the winter months, making them more prone to infections (Bruun et al., 2002). Although it is not possible to delineate the association between seasons and metritis incidence in this study, we know that the investigated dairy farms provided cows with sufficient roughage and high-quality concentrate during the winter. Hence, we can assume that factors other than feeding problems such as poor husbandry, poor cow comfort, and overcrowding may be an underlying cause of the frequent occurrence of metritis during the cold months.

The incidence of metritis increased with the presence of twinning $(\mathrm{OR}=3.3 ; P<0.001$; twin birth vs. single birth; Table 5). Among cows that had a twin birth once, the chance of having a difficult calving is high (more exposed to farmer-assisted calving) and thereby these cows are more prone to trauma of the uterus; trauma to the uterine wall can be a source of infection (Bruun et al., 2002).

The odds of metritis were greater for difficult calvings, with an incidence of $19.4 \%$ compared with $13.9 \%$ for normal calvings $(P<0.01$; OR $=1.4$; dystocia vs. normal; Table 5). Dystocia can increase the risk of trauma to the uterine wall and thereby increase the odds of metritis. This finding was not surprising and is supported by the literature (Gröhn et al., 1990; Kaneene and Miller, 1995; Bruun et al., 2002).

The odds of metritis differed significantly based on retained placenta status, with 53.7 versus $10.0 \%$ for abnormal and normal status, respectively $(\mathrm{OR}=15.2$; $P<0.001$; abnormal vs. normal; Table 5 ). The effect of retained placenta has previously been shown to greatly increase the odds of metritis (Gröhn et al., 1990; Kaneene and Miller, 1995; Bruun et al., 2002). The biological explanation could be that retained placental membranes pose a perfect environment for bacterial growth. Another possibility is a deficit in immune function because cows with retained fetal membranes have impaired neutrophil function, which may compromise their ability to expel the placenta after parturition (Kimura et al., 2002).

Among cows that had metritis once, the chance of having metritis again was $18.2 \%$. Our results indicate that previous occurrence of metritis is not a risk factor for having metritis in later lactations $(\mathrm{OR}=0.1 ; P=$ 0.61 ; no vs. yes; Table 5 ). In previous studies, effect of previous metritis as a risk factor for metritis has not been reported.

\section{Direct Losses Due to Incidence of Metritis}

Production and economic parameters used for calculating different cost components and total metritis costs are summarized in Table 6. Differences among farms in production and reproduction resulted in a large variation in total cost of metritis. This is mainly because of differences in the estimated milk losses and culling cost. The reduced amount of milk per cow per herd was $196.6 \mathrm{~kg}$ on average and varied from 91.1 to $390.0 \mathrm{~kg}$ across investigated farms. The average value of culling within farms varied from $\$ 555$ to $\$ 833$ per head, with an average of $\$ 702$ per head.

Fertility losses accounted for 35 to $47 \%$ of total costs. Discarded milk expenses were the next most important cost, accounting for 27 to $34 \%$ of total costs. Veterinary expenses ranged from 12 to $15 \%$ of metritis costs (Figure 1). Dijkhuizen et al. (1985) reported that prolonged days open and involuntary culling are the predominant reproductive cost factors in dairy herd management. These findings were confirmed by Drillich et al. (2001) and are supported by our results.

Among individual farms, metritis costs ranged from $\$ 146.4$ to $\$ 175.7$ with a mean of $\$ 162.3$ per case. The average total estimated cost of metritis was in the reported range of $\$ 106$ to $\$ 371$ per case in the literature (Bartlett et al., 1986; Drillich et al., 2001; Overton and Fetrow, 2008). Several factors explain the differences: different predictions for the effects of metritis on production and reproduction; culling in herds under different production systems; estimation methods; and purpose of study. For example, Drillich et al. (2001) conducted a financial analysis with 87 different cost scenarios for 3 treatment protocols that included costs for veterinary treatments, milk withdrawal, reproductive performance, and premature culling. They estimated an average of US $\$ 370.8$ per case per pregnancy through different treatment protocols, which was higher than our estimation. The cost of metritis reported by Bartlett et al. (1986) was lower because no effects on milk yield were included in the calculations.

It should be noted that the method presented here to calculate economic losses associated with metritis had shortcomings, such as use of ADMY (because average daily yield for the entire lactation is not the same as daily yield during the disease) and therapy duration (due to lack of precision in the measurement) to estimate the amount of discarded milk, together with the approach applied to estimate the reduction in milk production, which is not sensitive enough for an accurate 
Table 6. Estimated production and economic parameters used for the calculation of financial losses caused by metritis for the 4 investigated dairy farms of the Isfahan province of Iran

\begin{tabular}{|c|c|c|c|c|c|}
\hline \multirow[b]{2}{*}{ Variable $^{1}$} & \multicolumn{4}{|c|}{ Farm } & \multirow[b]{2}{*}{ Mean } \\
\hline & 1 & 2 & 3 & 4 & \\
\hline $\operatorname{ADMY}(\mathrm{kg} / \mathrm{cow})$ & 38.5 & 39.8 & 38.1 & 35.7 & 38.0 \\
\hline Average DT (d) & 4 & 4 & 5 & 4 & 4.3 \\
\hline $\operatorname{Disc}_{\text {milk }}(\mathrm{kg} /$ cow $)$ & 153.8 & 159.3 & 190.3 & 143.0 & 161.6 \\
\hline Milk losses $^{2}(\mathrm{~kg})$ & 91.1 & 119.8 & 390.0 & 185.3 & 196.6 \\
\hline Milk profit ${ }^{3}(\$ / \mathrm{kg})$ & 0.12 & 0.08 & 0.06 & 0.07 & 0.08 \\
\hline Longer open days $(\mathrm{d})$ & 14.7 & 16.9 & 17.0 & 19.2 & 17.0 \\
\hline Days open cost $(\$ / \mathrm{d})$ & 4.1 & 4.4 & 3.6 & 4.0 & 4.0 \\
\hline Time of veterinary service ( $\mathrm{h} /$ case) & 0.40 & 0.42 & 0.50 & 0.46 & 0.45 \\
\hline Cost of veterinary service (US $\$ / \mathrm{h}$ ) & 9.8 & 16.7 & 18.3 & 17.4 & 15.6 \\
\hline Herdsman's time (h/case) & 1.0 & 1.0 & 1.2 & 1.0 & 1.1 \\
\hline Cost of herdsman's time (US\$/h) & 1.81 & 1.66 & 1.16 & 1.41 & 1.51 \\
\hline Drug costs (US\$/metritis case) & 13.0 & 13.3 & 17.0 & 14.6 & 14.5 \\
\hline Probability of cow culled to abattoir (\%) & 0.9 & 0.8 & 0.8 & 1.0 & 0.9 \\
\hline Average value of culling (\$/head) & 795 & 833 & 555 & 626 & 702 \\
\hline Total costs $(\$ /$ case $)$ & 146.4 & 163.2 & 175.7 & 163.8 & 162.3 \\
\hline
\end{tabular}

${ }^{1} \mathrm{ADMY}=$ average daily milk yield; DT $=$ duration of therapy; Disc ${ }_{\text {milk }}=$ average amount of discarded milk calculated as ADMY (kg per cow) $\times$ infection period in which milk discarded (DT, d).

${ }^{2}$ Milk losses are the reduction in milk production and equal to differences in least squares means of healthy and affected cows.

${ }^{3}$ Milk profit $=$ milk sale price - milk production cost. Milk price is listed in Table 2.

calculation. More sophisticated economic modeling and accurate data are required to evaluate economic losses due to metritis based on type (clinical or puerperal) and parity mainly due to different incidence, consequences, and replacement costs. Regardless of the exact cost, reducing the risk of metritis through improving

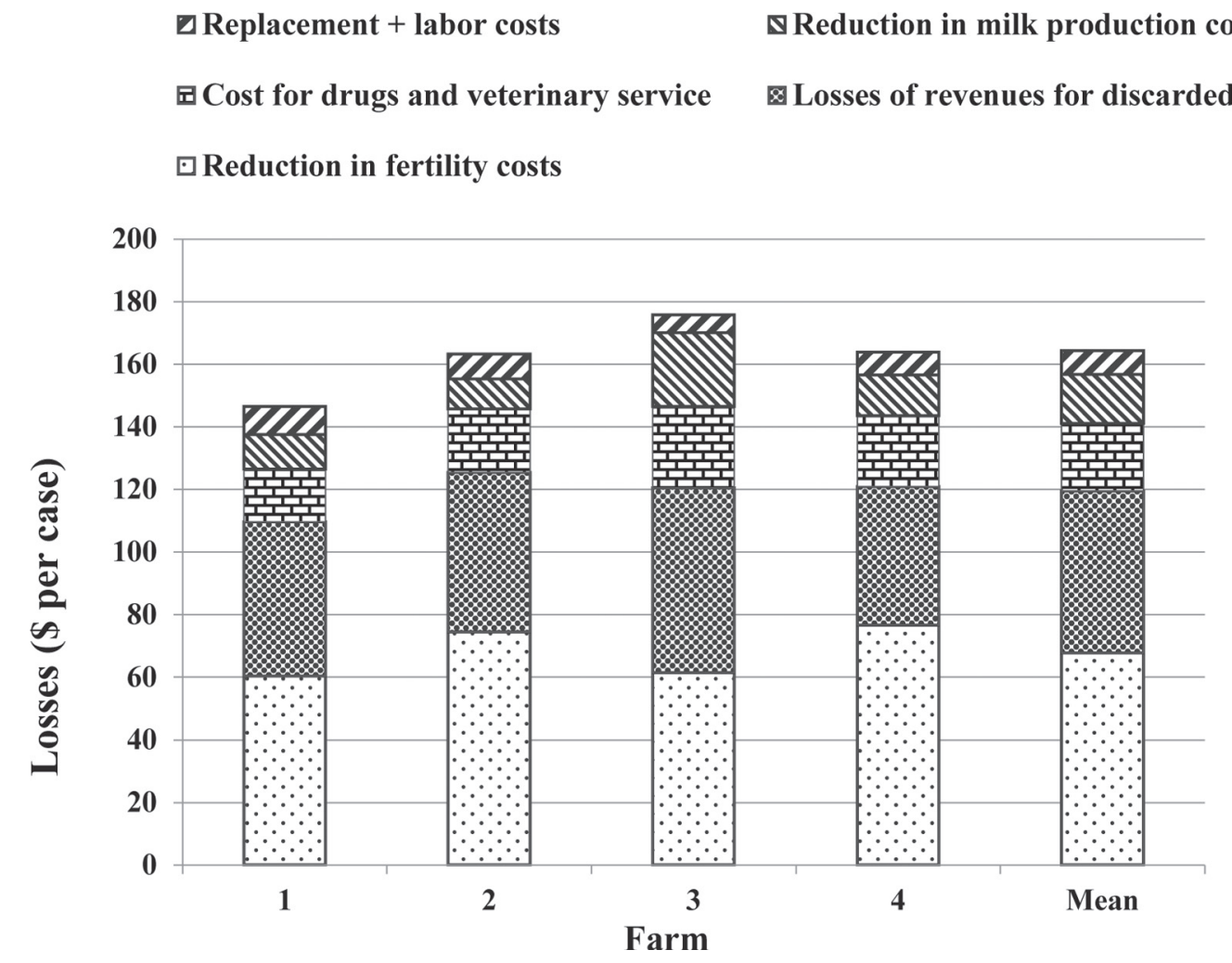

Figure 1. Average total financial losses caused by metritis in the 4 investigated dairy farms of Isfahan province, Iran. 
management and genetics could have significant gains for dairy farms.

\section{CONCLUSIONS}

The results obtained in this study provide important information about incidence, risk factors, and productive and reproductive consequences of metritis that can be used in a cost-benefit analysis for management factors in metritis control programs. The model we have proposed to calculate metritis costs could be used to estimate economic losses for metritis in other developing countries, where farm production and economic data are generally scarce. However, our results should be interpreted with caution in other regions of the world because of the low representativeness of the applied method for calculations of discarded milk and reduced milk yield associated with metritis and the particular economic situation in Iran at the time of the study.

\section{ACKNOWLEDGMENTS}

The authors are grateful to Mehdi Safahani-Langerodi (FKA Agriculture and Animal Husbandry, Isfahan, Iran), and farmers for participating in the study. Special thanks to 3 anonymous reviewers for their constructive suggestions.

\section{REFERENCES}

Bartlett, P. C., J. H. Kirk, M. A. Wilke, J. B. Kaneen, and E. C. Mather. 1986. Metritis complex in Michigan Holstein-Friesian cattle: incidence, descriptive epidemiology and estimated economic impact. Prev. Vet. Med. 4:235-248.

Benzaquen, M. E., C. A. Risco, L. F. Archbald, P. Melendez, M. J. Thatcher, and W. W. Thatcher. 2007. Rectal temperature, calving-related factors, and the incidence of puerperal metritis in postpartum dairy cows. J. Dairy Sci. 90:2804-2814.

Bruun, J., A. K. Ersbøll, and L. Alban. 2002. Risk factors for metritis in Danish dairy cows. Prev. Vet. Med. 54:179-190.

Cabrera, V. E. 2012. A simple formulation and solution to the replacement problem: A practical tool to assess the economic cow value, the value of a new pregnancy, and the cost of a pregnancy loss. J. Dairy Sci. 95:4683-4698.

CBI. 2014. The Central Bank of Iran. Accessed May 9, 2015. http:// www.cbi.ir.

Dijkhuizen, A. A., J. Stelwagen, and J. A. Renkema. 1985. Economic aspects of reproductive failure in dairy cattle. I. Financial loss at farm level. Prev. Vet. Med. 3:251-263.

Dorshorst, N. C., M. T. Collins, and J. E. Lombard. 2006. Decision analysis model for paratuberculosis control in commercial dairy herds. Prev. Vet. Med. 75:92-122.

Drillich, M., O. Beetz, A. Pfutzner, M. Sabin, H. J. Sabin, P. Kutzer, H. Nattermann, and W. Heuwieser. 2001. Evaluation of a systemic antibiotic treatment of toxic puerperal metritis in dairy cows. J. Dairy Sci. 84:2010-2017.

Dubuc, J., T. F. Duffield, K. E. Leslie, J. S. Walton, and S. J. LeBlanc. 2011. Effects of postpartum uterine diseases on milk production and culling in dairy cows. J. Dairy Sci. 94:1339-1346.

Elkjær, K., R. Labouriau, M. L. Ancker, H. Gustafsson, and H. Callesen. 2013. Large-scale study on effects of metritis on reproduction in Danish Holstein cows. J. Dairy Sci. 96:372-377.
Fourichon, C., H. Seegers, and X. Malher. 2000. Effect of disease on reproduction in the dairy cow: A meta-analysis. Theriogenology $53: 1729-1759$

Giuliodori, M. J., R. P. Magnasco, D. Becu-Villalobos, I. M. LacauMengido, C. A. Risco, and R. L. de la Sota. 2013. Metritis in dairy cows: Risk factors and reproductive performance. J. Dairy Sci. 96:3621-3631.

Goshen, T., and N. Y. Shpigel. 2006. Evaluation of intrauterine antibiotic treatment of clinical metritis and retained fetal membranes in dairy cows. Theriogenology 66:2210-2218.

Gröhn, Y. T., H. N. Erb, C. E. Mcculloch, and H. S. Saloniemi. 1990. Epidemiology of reproductive disorders in dairy cattle: associations among host characteristics, disease and production. Prev. Vet. Med. 8:25-39.

Gröhn, Y. T., P. J. Rajala-Schultz, H. G. Allore, M. A. DeLorenzo, J. A. Hertl, and D. T. Galligan. 2003. Optimizing replacement of dairy cows: modeling the effects of diseases. Prev. Vet. Med. $61: 27-43$.

Huzzey, J. M., D. M. Veira, D. M. Weary, and M. A. G. von Keyserlingk. 2007. Prepartum behavior and dry matter intake identify dairy cows at risk for metritis. J. Dairy Sci. 90:3220-3233.

Iran Meteorological Organization. 2014. Esfahan Meteorological Organization. Accessed Nov. 12, 2014. http://www.irimo.ir.

Kaneene, J. B., and R. Miller. 1995. Risk factors for metritis in Michigan dairy cattle using herd- and cow-based modeling approaches. Prev. Vet. Med. 23:183-200.

Kimura, K., J. P. Goff, M. E. Kehrli, and T. A. Reinhardt. 2002. Decreased neutrophil function as a cause of retained placenta in dairy cattle. J. Dairy Sci. 85:544-550.

LeBlanc, S. J., T. F. Duffield, K. E. Leslie, K. G. Bateman, G. P. Keefe, J. S. Walton, and W. H. Johnson. 2002. Defining and diagnosing postpartum clinical endometritis and its impact on reproductive performance in dairy cows. J. Dairy Sci. 85:2223-2236.

Melendez, P., J. McHale, J. Bartolome, L. F. Archbald, and G. A. Donovan. 2004. Uterine involution and fertility of Holstein cows subsequent to early postpartum $\mathrm{PGF}_{2 \alpha}$ treatment for acute puerperal metritis. J. Dairy Sci. 87:3238-3246.

Opsomer, G., Y. T. Gröhn, J. Hertl, M. Coryn, H. Deluyker, and A. de Kruif. 2000. Risk factors for post partum ovarian dysfunction in high producing dairy cows in Belgium: A field study. Theriogenology 53:841-857.

Østergaard, S., and Y. T. Gröhn. 1999. Effect of diseases on test day milk yield and body weight of dairy cows from Danish research herds. J. Dairy Sci. 82:1188-1201.

Overton, M., and J. Fetrow. 2008. Economics of postpartum uterine health. Pages 39-44 in Proc. Dairy Cattle Reproduction Council Convention, Omaha, NE.

Rajala, P. J., and Y. T. Gröhn. 1998. Effects of dystocia, retained placenta, and metritis on milk yield in dairy cows. J. Dairy Sci. $81: 3172-3181$.

Roine, K., and H. Saloniemi. 1978. Incidence of some diseases in connection with parturition in dairy cows. Acta Vet. Scand. 19:341353

Shahinfar, S., A. S. Kalantari, V. E. Cabrera, and K. Weigel. 2014a. Prediction of retention pay-off using a machine learning algorithm. J. Dairy Sci. 97:2949-2952.

Shahinfar, S., D. Page, J. Guenther, V. E. Cabrera, P. Fricke, and K. Weigel. 2014b. Prediction of insemination outcomes in Holstein dairy cattle using alternative machine learning algorithms. J. Dairy Sci. 97:731-742.

Sheldon, I. M., G. S. Lewis, S. LeBlanc, and R. O. Gilbert. 2006. Defining postpartum uterine disease in cattle. Theriogenology 65:1516-1530.

Urton, G., M. A. G. von Keyserlingk, and D. M. Weary. 2005. Feeding behavior identifies dairy cows at risk for metritis. J. Dairy Sci. 88:2843-2849

Wittrock, J. M., K. L. Proudfoot, D. M. Weary, and M. A. G. von Keyserlingk. 2011. Metritis affects milk production and cull rate of Holstein multiparous and primiparous dairy cows differently. J. Dairy Sci. 94:2408-2412. 